\title{
Role of Nurse as Care Giver and Advocator In The Ward, Era National Health Insurance (NHI) Program
}

\author{
Indriati, Mugi Hartoyo, Sri Utami Dwiningsih ${ }^{1}$ \\ ${ }^{1}$ Poltekkes Kemenkes Semarang, Indonesia \\ Corresponding author : iinbimi1234@gmail.com
}

\begin{abstract}
Background: There are many National Health Insurance (NHI) participants who do not yet understand the mechanism of NHI services, including clients who are hospitalized. The phenomena that exist on the field, that the client will enlist the help of health professionals who are always in the ward, especially nurses, to provide information on all matters, including NHI. On the other hand, nurses have a major role in caring for clients, based on their duties and functions.

Purpose : This study aims to determine if there is expansion of the role of nurses as care giver and advokator in the inpatient unit, era NHI program.

Methods : This research is a descriptive study of the role of nurses as care giver and advokator in inpatient era NHI program, employing triangulation method. Respondents were 64 inpatient clients registered as NHI participants in the Hospital Semarang assigned by proportional simple random sampling, and four nurses.

Result : The results showed that there are expanding the role of nurses as care giver and advocator in the inpatient unit, era NHI program.

Conclusion : With the implementation of NHI program, the roles of nurses as care giver and advokator has expanded in the inpatient unit. NHI/NHI parties need to disseminate information relating to NHI to nurses, as well as the need to be given compensatory reward for nurses.
\end{abstract}

Keywords : Nurse's role, Care Giver, National Health Insurance (NHI) era

How to Cite: Indriati, I., Hartoyo, M., Dwiningsih, S. (2018). Role of Nurse as Care Giver and Advocator In The Ward, Era National Health Insurance (NHI) Program. Journal Of Nursing Practice, 2(1), 1-6. https://doi.org/10.30994/jnp.v2i1.36 


\section{BACKGROUND}

As a 1-year health insurance program, there are still many NHI participants who do not understand the mechanism of NHI services, including inpatient clients. While at the hospital, nurses are 24 hours assisting clients. In times of sadness, pain, and need of information (including information about the NHI program); of course the client will ask the help of health workers who are always there in the room, namely nurses. The client assumes that the nurse must know a lot about NHI, including about financing, service flow, administrative requirements to get free service and others. Moreover, not all inpatient clients come to the hospital with referral letters from the Puskesmas or family doctors. Often due to emergency conditions, clients come directly to the hospital and eventually treated in the inpatient ward without carrying a letter of reference and not understand the requirements and flow of NHI. Finally, the nurse must provide information or educate the client about NHI.

In accordance with the Consortium of Health Sciences in 1989, nurses have a role as care giver, educator, advocate, counselor, collaborator, researcher, and reformer. In the era of the NHI program, are the roles (especially the role of nurses as care giver and advocate) experiencing an extension and how is the picture of the role?

\section{OBJECTIVE}

This study aims to determine if there is expansion of the role of nurses as care giver and advokator in the inpatient unit, era National Health Insurance program.

\section{METHODS}

This research is a descriptive research. Judging from data collection techniques, this research is a mixed methodology. A mixed method is a method that combines both qualitative and quantitative approaches. Triangulation research methods to compare information obtained from clients as recipients of nursing care and nurses as nursing care. The goal is to guarantee the level of data confidence and prevent subjectivity. Triangulation method is done by using survey method and indepth interview method.

The research variables include the role of nurse as care giver and educator in the inpatient room, the era of NHI program. Location of research inpatient wards Semarang General Hospital (Kresna King Room, Nakula, Bima and Yudistira). Population and sample in this research adalalah NHI participant client at inpatient ward of Semarang General Hospital. The number of sample 64 with the average count of the number of patients participating NHI inpatient room an average of 64 people per day. The sampling technique is proportional random sampling.

Data collection tool for quantitative research in the form of structured questionnaires. The questionnaire consists of several statements. All statements are type favorable. Qualitative data was obtained by using interview guideline which was arranged semistruktural, that is in the form of questions that nurse about its role in inpatient room of NHI era. Results from questionnaires and in-depth interviews were then cross-checked.

Data analysis is done in the order of quantitative analysis then qualitative analysis. Quantitative data were analyzed up to the univariate stage to describe the characteristics of each variable. The data are presented in the form of frequency distributions with percentage sizes to answer research questions whether there is a role extension or not.

Qualitative data is written in the form of field notes and copied in transcript form. Data analysis by using thematic analysis is by making keywords, categories, and themes 
about the topic being studied. Qualitative data analysis is used to describe or describe how the description of the role of nurses as care giver and advocate in the inpatient room, the era of NHI program.

\section{RESULTS}

a. Description of Role of Nurse as Giver Care in Inpatient Room, NHI Program Era 1. Quantitative Data

\begin{tabular}{cccc}
\hline No & $\begin{array}{c}\text { Nurse as } \\
\text { Care Giver }\end{array}$ & $\begin{array}{c}\text { Frequency } \\
(\mathbf{F})\end{array}$ & $\begin{array}{c}\text { Prosentase } \\
(\mathbf{\%})\end{array}$ \\
\hline 1. & Expansion & 60 & 93,75 \\
\hline 2. & No Expansion & 4 & 6,25 \\
\hline & Total & 64 & 100 \\
\hline
\end{tabular}

Table. 1 Frequency Distribution Role of Nurse As Care Give

2. Qualitative Data

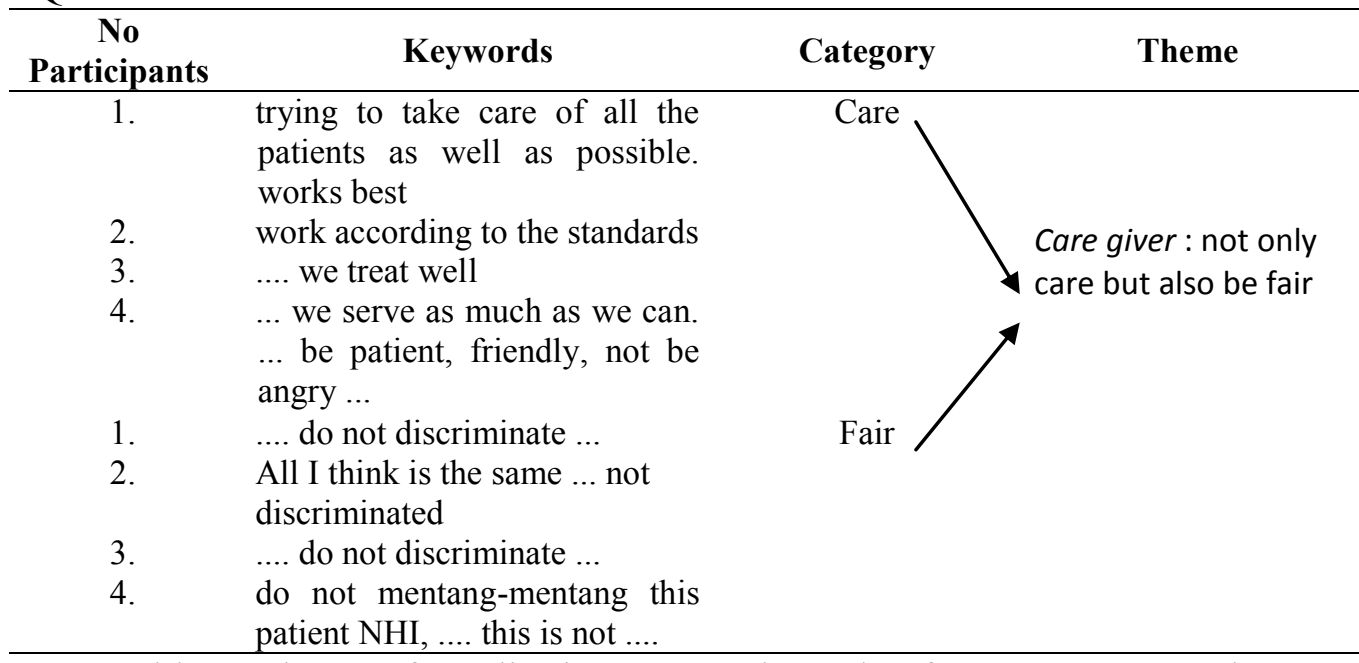

Table 2. Theme of Qualitative: Data The Role of Nurse As Care Giver

b. Description of Nurse's Role as Advocate of Inpatient Room, NHI Program Era

1. Quantitative Data

\begin{tabular}{|cccc|}
\hline No & $\begin{array}{c}\text { Nurse as } \\
\text { Care Giver }\end{array}$ & $\begin{array}{c}\text { Frequency } \\
(\mathbf{F})\end{array}$ & $\begin{array}{c}\text { Prosentase } \\
(\mathbf{\%})\end{array}$ \\
\hline 1. & Expansion & 62 & 96,9 \\
\hline 2. & $\begin{array}{c}\text { No } \\
\text { Expansion }\end{array}$ & 2 & 3,1 \\
\hline & Total & 64 & 100 \\
\hline
\end{tabular}

Table 3. Frequency Distribution Role of Nurse As Advocate

2. Qualitative Data

\begin{tabular}{|c|c|c|c|}
\hline $\begin{array}{c}\text { No } \\
\text { Participants }\end{array}$ & Keywords & Category & Theme \\
\hline 1 & $\begin{array}{l}\text { equipped not yet the } \\
\text { requirements? }\end{array}$ & $\begin{array}{l}\text { Disseminate } \\
\text { various }\end{array}$ & \\
\hline 2. & His letters are complete? & information from & \\
\hline
\end{tabular}

3. dah complete not the letters? In NHI to clients 


\begin{tabular}{|c|c|c|c|}
\hline 4. & $\begin{array}{l}\text { the future have given copies of } \\
\text { NHI and KTP cards yet? } \\
\text { Is not NHI Mom? Was } \\
\text { complete not his letters? Let } \\
\text { me do not have to pay again }\end{array}$ & & \\
\hline $\begin{array}{l}1 . \\
2 . \\
3 . \\
4 .\end{array}$ & $\begin{array}{l}\text { Always we say, father, mother } \\
\text { want to be injected .... After } \\
\text { injection ... we asked ... how it } \\
\text { feels ... a little pain ... no } \\
\text { problem..the important thing } \\
\text { heal .. } \\
\text { If you want action, ... I explain } \\
\text { first } \\
\text { Yo we must explain everything } \\
\text { if we want to take action } \\
\ldots \text { so we were taught in school. } \\
\text { Yes I always talk if you want } \\
\text { to do what. Inject well first? } \\
\text { Later even not paid NHI lho ... } \\
\text { can lose } \\
\text { Let me not pay } \\
\text { Kan can be free } \\
\text { Let me do not have to pay } \\
\text { again }\end{array}$ & $\begin{array}{l}\text { provide } \\
\text { information prior } \\
\text { to approval of the } \\
\text { nursing actions } \\
\text { given to the } \\
\text { patient }\end{array}$ & $\begin{array}{l}\text { Advocate: } \\
\text { protect the rights of } \\
\text { clients }\end{array}$ \\
\hline
\end{tabular}

Table 4. Theme of Qualitative Data: The Role of Nurse As Advocate

\section{DISCUSSION}

\section{Description of Role of Nurse as Giver Care in Inpatient Room, NHI Program Era}

The quantitative and qualitative data above reinforce each other is that there is an extension of the role of nurses as care giver in the inpatient room, the era of NHI program. Nurses are not only required to care and take action according to SOP (standart operasional prosedur), but also demanded to be able to be fair, not discriminating between the clients and general NHI. The meaning of the word fair according to Big Indonesian Dictionary (KBBI) is the same weight; not heavy-side; impartiality, taking sides with the right; hold on to the truth; duly; not arbitrary.

With the NHI program, the nurses must take action not one-sided, both to the client NHI and general. We know that the honor or service of the client NHI for the nurse percentage is very small and given many months after the client returns; but the prawat must remain "care". This is in theory, which says that people perceive professional nurses as carers who have ethics and caring in nursing services (Liu, Moke \& Wong, 2006). Caring is the essence of nursing, the core of nursing moral values that are based on human values and prioritize the well-being of others, in this case the clients and their families (Leininger, 1997 \& Watson, 2004).

In the caring there is also a sense of keadilian. Caring in nursing involves treating clients humanely and wholely as human beings different from other human beings. Form of intervention that is not only a technical ability but accompanied by warmth, kindness, compassion. Clinical Caritas Process (CCP) comes from the Greek cherish, which means 
giving love and special attention. Clinical Caritas Process is a practice of patient care with heart, awareness, and love.

There are ten themes of caring attitude according to Watson (2004). Theme consists of caring attitude to the needs of clients and family, responsible, always ready to meet the needs of clients, friendly, calm and patient in serving clients, motivate clients, empathy for the client and family, doing therapeutic communication, sincere and skillful attitude.

The nurse is the largest health worker in the hospital with $48 \%$. That is, in the hospital, nurses act as the largest internal customers (internal host shopping) that greatly affect the image of a hospital. With the caring and fair attitude of nurses, it can be used as a media campaign for hospitals and NHI to get external customers (clients)

\section{Description of Nurse's Role as Advocate of Inpatient Room, NHI Program Era}

Tables 3 and 4 show in the era of NHI, the role of nurse as advocate extends, among others, nurses disseminate various information from NHI regarding the flow and mechanism of service, as well as the rights and obligations of NHI participants. Nurses also maintain and protect the rights of patients to NHI membership that is the right to get free health services in accordance with applicable regulations. On the other hand, the dissemination of information from the NHI to the nurses is very minimal. Researchers see, NHI more dissemination of information to the first level faskes, both family doctors and health centers. Though the reality in the field, although in the hospital there NHI Center, but they are not open 24 hours and often times faced with a choice that must be decided in a short time. For example, doctors advise for immediate medical action or purchase drugs not in the NHI; so the client must spend money in small amounts. They are confused, to whom he must complain to find a solution. While NHI Center is closed. Finally to the nurses they complain to immediately be able to take the best keputuasan to save the lives of family members

\section{CONCLUSION}

The era of the NHI program, the role of nurse as a care giver and advocate, has expanded. As a care giver, nurses are not only required care, but also must be fair to general clients and NHI participants. As an advocate, the nurse is not only required to be able to provide other information in approval of the nursing actions given to the client, but also to be able to disseminate information from NHI to the client in order to be able to maintain and protect the rights of the clients of the NHI participant.

\section{REFERENCES}

Ary, Donald, Lucy Cheser Jacobs, dan Christine K. Sorensen, Introduction to Research in Education, Eight Edition, USA: Wadsworth Cengage Learning. 2010

Bodgan, Robert C. dan Sari Knopp Biklen, Qualitative Research for Education: an Introduction to Theories and Methods, Fifth Edition, USA: Pearson. 2006

Bungin, Burhan, Penelitian Kualitatif: Komunikasi, Ekonomi, Kebijakan Publik, dan Ilmu Sosial Lainnya, Jakarta: Kencana. 2010

Depkes RI. Pelayanan Keperawatan Dalam Sistem Pelayanan Kesehatan. Jakarta : Depkes RI. 2009. (online). (http://staff.ui.ac/internal/132014715/material/SISYANWATDLMSISYANKES.ppt diakses 24 Maret 2013

Ellina, A., Suwarno, S., \& Fawzi, A. (2018). The Precision Of The Giving Of The Drug Based On Service Identifikation Of Patien Compliance At "Darmayu" General Hospital Ponorogo. Journal Of Nursing Practice, 1(2), 7-11. https://doi.org/10.30994/jnp.v1i2.27 
Gunarto, G., Setiyani, D., Iswahyudi, P., \& Hildania, H. (2018). Nursing Role In The Implementation Of Emergency Patients With Interruption Of The Cardiovascular Systemat The Review Of Nurse Knowledge In Aisyiyah Hospital Ponorogo. Journal Of Nursing Practice, 1(2), 41-46. https://doi.org/10.30994/jnp.v1i2.32

Hidayat Syah. Pengantar Umum Metodologi Penelitian Pendidikan Pendekatan Verivikatif. P ekanbaru : Suska Pres. 2010

Kementerian Kesehatan Republik Indonesia.. Buku Pegangan Sosialisasi Jaminan Kesehatan Nasional (JKN) dalam Sistem Jaminan Sosial Nasional. 2013

Liu, J.E., Moke, E., \& Wong, T.. Caring in nursing. 2006. Didapat dari http://search.epnet.com diperoleh 17 Juli 2011

Nurachmah, E. How nurses express their caring behavior to client with special needs. 2001. http://www.pdpersi.co.id/pdpersi/news diperoleh 24 Juli 2011

Patton, Michael Quinn Metode Evaluasi Kualitatif, Terjemah: Budi Puspo Priyadi, Yogyakarta: Pustaka Pelajar. 1991

Potter \& Perry. Fundamental of nursing: Concep, process and practice. $4^{\text {th }}$ ed. Alih bahasa: Yasmin, A., dkk. Jakarta: EGC. 2005.

Raharjo, Mudjia, Triangulasi dalam Penelitian Kualitatif, dari http://mudjiaraharjo.com/ Met. Penelitian Pendidikan/penting/270-triangulasi-dalam-penelitian-kualitatif.html (Jum'at, 15 Oktober 2010)

Rafii, F., Oskouie, F. \& Nikravesh, M. Major determinant of caring behavior. 2004.http://www.hcs.harvard.edu diperoleh 24 Juli 2011

Rauner, D.M. Caring research and ideas. 2006 http://en.wikipedia.org/wiki/nursing theory diperoleh 17 Juli 2011

Sanapiah Faisal. Format-format Penelitian Sosial. Jakarta : Rajawali Pers. 2008

Sarwono, Sarlito Wirawan.. Psikologi Social. Jakarta : Balai Pustaka. 2002

Saryono. Metodologi Penelitian Kesehatan : Penuntun Praktis Bagi Pemula. Yogyakarta : Mitra Cendikia. 2011

Sobur ,Alex.. Psikologi Umum. Bandung: Pustaka Setia. 2003

Tappen, R.M., Sally, A.W., Diana, K.W. Essensial of nursing leadership and management. 3th ed. Philadelphia: F.A. Davis. 2004

Thabrany, Hasbullah. 2004. Jaminan Kesehatan Nasional Dalam SJSN. [Online] Available at : http://staff.ui.ac.id/internal/140163956/material/MengapaperluAskesnas.pdf Accessed 13 Mei 2013

Walgito, Bimo. Psikologi Social Suatu Pengantar, Yogyakarta: Andi Yogyakarta. 2003

Watson, J.(2004). Original center for human caring. http://www2.uchsc.edu diperoleh 17 Juli 2011 